\title{
Monitoring of Population of Scolytinae in Olive Culture
}

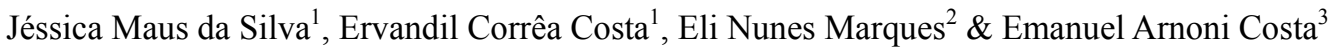 \\ ${ }^{1}$ Department of Plant Protection, University Federal of Santa Maria, Santa Maria, Rio Grande do Sul, Brazil \\ ${ }^{2}$ Department of Forest Science, University Federal of Paraná, Curitiba, Paraná, Brazil \\ ${ }^{3}$ Department of Forestry Engineering, State University of Santa Catarina, Lages, Santa Catarina, Brazil \\ Correspondence: Jéssica Maus da Silva, Department of Plant Protection, University Federal of Santa Maria, \\ Santa Maria, Brazil. E-mail: smausjessica@gmail.com
}

Received: April 29, 2018

doi:10.5539/jas.v10n8p457

\author{
Accepted: June 3, $2018 \quad$ Online Published: July 15, 2018 \\ URL: https://doi.org/10.5539/jas.v10n8p457
}

\begin{abstract}
Monitoring of insects is important to analyze the species present in culture of economic interest, to verify the period of highest incidence and quantify the damages caused by the pest insects. Here, we aim to assess the diversity of bark beetles in an olive orchard. The experiment was assessed in fortnightly series throughout a year and conducted with a completely randomized experimental design, consisting of three treatments: T1: homogeneous olive culture; T2: heterogeneous olive culture; T3: border area. An ethanol trap was used for the sampling of bark beetles. The species Hypothenemus eruditus, Xyleborus linearicolis and Hypothenemus seriatus showed greater abundance among the treatments. The decrease of abundance, diversity and dominance of bark beetles occurred in the heterogeneous culture (T2). Homogeneous cultures (T1) are more susceptible to the attack of pest-insects due to the lower ecological balance among associate, predator or parasitoid insects. Border areas (T3) showed an increased diversity of arboreal species, favoring the higher incidence of insects. In spring, there is a greater incidence of bark beetles, what reinforces the need for monitoring during this period. So far, there are no evidences of bark beetles infesting olive trees in the area, or the presence of Phloeotribus scarabaeoides, which is the pest bark beetle of olive cultures.
\end{abstract}

Keywords: bark beetles, diversity, Olea europea, population fluctuation

\section{Introduction}

Many habitats become altered with the advance of monocultures, creating an imbalance of fauna and flora. These factors are usually related to the continuous use of agricultural chemicals and forest defragmentations. The occurrence of pest-insects tends to increase when there is no control or ecological balance among associate, predator and parasitoid insects.

In general, pest-insects cause damage to plants and can be considered disease vectors, thus limiting the development, growth and reproduction of forest and agricultural cultures (Wood, 1982; Flechtmann et al., 1995). Among the pest-insects that cause major damages are the Coleoptera, specially coleoborers belonging to the family Curculionidade, and the subfamily Scolytinae (Gallo et al., 2002; Souza et al., 2016).

Bark beetles are considered secondary pests that develop under natural conditions in trees that are stressed, wounded, with nutritional deficiency, or that suffered influence of fires or lightnings (Wood, 1982). This subfamily has phytophagous species (bark beetles) that feed from the internal part of wood. Also, there are xylomycetophagous species (ambrosia beetles) that introduce and cultivate symbiotic fungi inside the host plant and use them as primary food source. From the xylomycetophagous species, the genus Xyleborus is one of the bark beetles that cause major damages to wood (Beaver, 1977; Moeck, 1981).

Bark beetles must be constantly monitored since they restrict the vitality and production of some agroforest cultures. There have been records of bark beetles that damaged several host plants such as Eucalyptus spp. (Bernardi et al., 2010), Pinus nigra and Pinus sylvestris sp. (Akuzzu et al., 2017), Persea borbonia (Hanula et al., 2008), Ricinus communis (Egonyu et al., 2017) and Coffea canephora (Silva et al., 2017).

In olive culture, the species Phloeotribus scarabaeoides (Coleoptera: Curculionidae: Scolytinae), also known as olive bark beetles, is considered a pest species because they damage living trees or pruned branches (Rodríguez et al., 2003). The adult insect causes the major damages to olive trees, forming galleries in the wood to feed and 
develop (Ruano et al., 2010). It is estimated that the attack of $P$. scarabaeoides in adult orchards can reduce approximately $75 \%$ of the potential yield (González \& Campos, 1994), and the attack to young plantings cause risks to plants inducing their mortality (Rodríguez et al., 2003).

The states of Minas Gerais, São Paulo, Santa Catarina and Rio Grande do Sul are the main investors in olive culture in Brazil (Coutinho et al., 2015), what reinforces the need for information and research regarding the phytosanitary safety of olive orchards. In this sense, this study aimed to describe and characterize ecological parameters of bark beetles and their temporal alterations associated to meteorological variables measured in fortnightly series throughout a year of monitoring.

When considering the damage that species of the subfamily Scolytinae cause in several host plants, this study aimed to assess qualitatively and quantitatively the diversity of bark beetles in an olive orchard. The specific objectives were: (a) identify individuals at species level; (b) assess abundance, richness and diversity; (c) investigate the behaviour of abundance, richness and diversity throughout the seasons; and (d) determine the similarity between the treatments analyzed in relation to richness of bark beetles.

\section{Material and Methods}

\subsection{Characterization and Location of the Study Area}

The experiment was performed in the municipality of Formigueiro, Rio Grande do Sul, in an area of olive

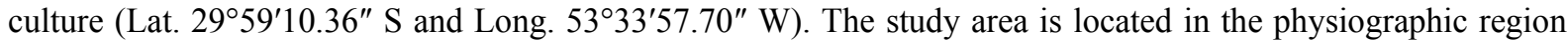
of Central Depression, considered a transition zone between the Atlantic Forest biome and the Pampa (IBGE, 2004).

The terrain is slightly wavy, and according to Köppen classification, the climate is humid subtropical with hot summer $\left(\mathrm{CFa}\right.$ ), average temperature and precipitation are $18.7^{\circ} \mathrm{C}$ and $1,648 \mathrm{~mm}$, respectively (Alvares et al., 2013). The soil is described as podzolic soil in the elevations, and albaqualf and gleysol in the lower altitude areas (Streck et al., 2008). The meteorological variables (Figure 1) such as relative humidity, precipitation and temperature were obtained from the database of the Instituto Nacional de Meterorologia (INMET). Data were assessed monthly over a period of twelve months, from June 2016 to May 2017.

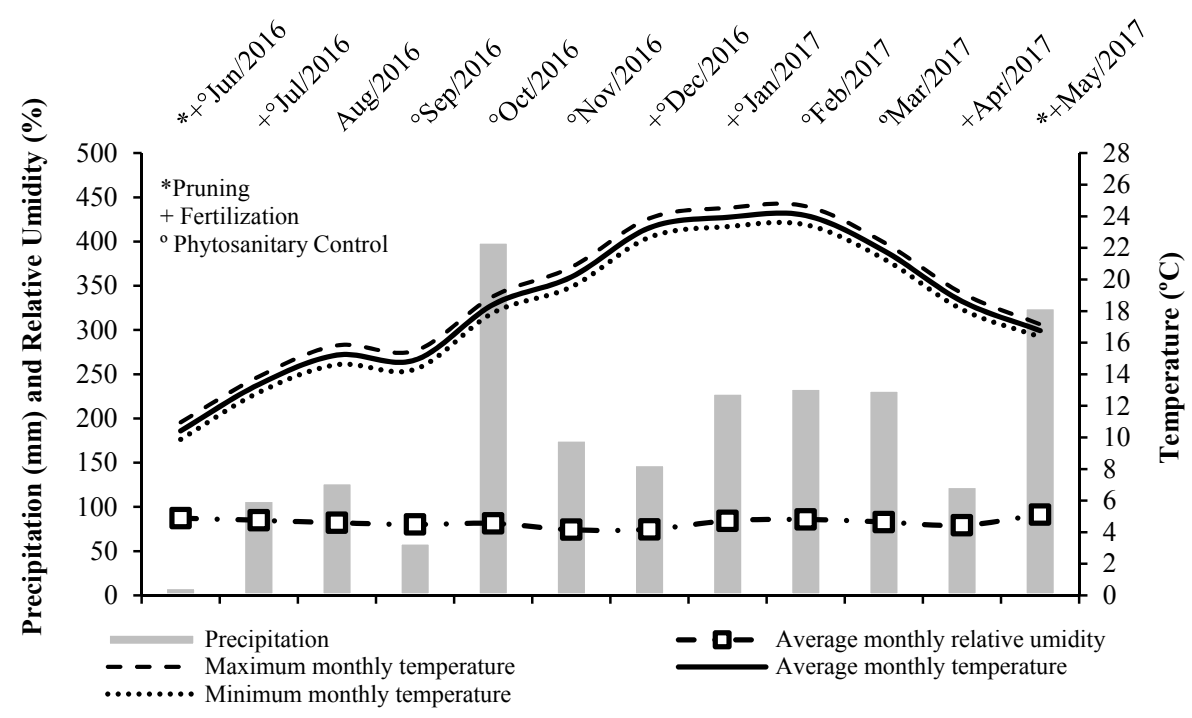

Figure 1. Meteorological variables and silvicultural activities carried in the olive orchard

\subsection{Experimental Design}

The experimental design used was completely randomized unbalanced, considering three treatments: T1: homogeneous olive culture, nine years old, the cultivar of the area is Arbequina, with spacing of 9.0 meters between lines, and 2.5 meters in the line. The planting area corresponds to $2.3 \mathrm{ha}$; T2: heterogeneous area of olive culture, with trees of seven years old. In this area, three cultivars were planted, including pollinators, which are: Arbosana, Arbequina, and Koroneiki. The planting spacing is 6.0 meters between lines and five 5.0 meters in 
the line. The planting area is 2.0 ha; T3: border area, consisting of reforestation of eucalyptus, native forest, and meadows.

The sampling sites were determined from the coordinates of each tree obtained with a global positioning system (GPS) model Garmin Etrex 20. Thus, the trees were randomized in each sites sampling, with 15, 17 and 7 for T1, $\mathrm{T} 2$, and $\mathrm{T} 3$, respectively.

\subsection{Maintenance and Phytosanitary Control of the Experimental Area}

In order to maintain the olive orchard productive, it is necessary to perform annual silvicultural interventions such as pruning, fertilization, and phytosanitary control (Figure 1). These interventions were performed from June 2016 to May 2017, in order to observe whether these activities influence on the distribution of Scolytinae fauna.

\subsection{Sampling of Scolytinae Fauna}

The collection of individuals of the subfamily Scolytinae (Coleoptera: Curculionidae) was performed fortnightly for a period of twelve months, from June 2016 to May 2017, in a total of 23 collections. Ethanol traps adapted from the model of Murari et al. (2012) were installed for the sampling of individuals. One trap was installed in each sampling site, positioned at $1.30 \mathrm{~m}$ above ground, between the medial and lower thirds of trees, and twenty meters apart from each other.

The collected insects were stored in alcohol $70 \%$ and taken to the Laboratory of Forest Entomology at Universidade Federal de Santa Maria (UFSM) where the screening of samples was performed. Insects were subsequently morphotyped, tagged, stored in microtubes with alcohol $70 \%$ to preserve the material, and identified at species level by an expert.

\subsection{Analyses of Scolytinae Fauna}

The ecological parameters analyzed were abundance $(\mathrm{N})$, species richness (S), Shannon diversity index (H'), Simpson's dominance index (D), Pielou's evenness (J'), and Jaccard (Sj) and Bray-Curtis (Sbc) similarity indices (Brower \& Zar, 1984; Magurran, 2013; Souza \& Soares, 2013). The equations referring to the analyzed parameters are described in Table 1.

Table 1. Ecological paramenters measured for analyse of bark beetles fauna

\begin{tabular}{ll}
\hline Parameters & Expressions \\
\hline Shannon diversity index (H') & $H^{\prime}=\frac{N \times \ln (N)-\sum_{i=1}^{S} n_{i} \times \ln \left(n_{i}\right)}{N}$ \\
Simpson's dominance index (D) & $D=1-\frac{\sum_{i=1}^{S} n_{i}\left(n_{i}-1\right)}{N(N-1)}$ \\
Pielou's evenness index (J') & $J^{\prime}=\frac{H^{\prime}}{H^{\prime}{ }_{\max }}$ \\
Jaccard similarity index (Sj) & $S j=\frac{c}{a+b-c}$ \\
Bray-Curtis similarity index (Sbc) & $S b c_{i i^{\prime}}=\frac{\sum_{J=1}^{J}\left|n_{i j}-n_{i j}^{\prime}\right|}{n_{i}+n_{i^{\prime}+}}$ \\
\hline
\end{tabular}

Note. $\overline{\mathrm{N}}=$ total number of individuals sampled; $n_{i}=$ number of individuals sampled for species; $\mathrm{H}^{\prime}{ }_{\max }=\ln (\mathrm{S}) ; \mathrm{S}$ $=$ total number of species sampled; $a=$ number of species presents in the treatment $1 ; b=$ number of species presents in the treatment 2; $c=$ number of species common to both treatment; $n_{i j}>0$, in sense: $n_{i^{\prime} j}=0$.

\subsection{Statistical Analyses}

The Tukey-Kramer test was used to assess abundance among treaments. Shannon diversity index (H') was compared among treatments through the Hutcheson t-test (Hutcheson, 1970). In orded to verify the behaviour of treatments throughout time, the analysis of variance (ANOVA) with repeated measures was performed for abundance and richness.

For the parameters of abundance and species richness with repeated measures ANOVA, a constant of 0.5 was added to these variables since they showed several values equal to zero (0), this procedure has been described by Yamamura (1999). Then, for the achievement of data normality, a transformation of these variables was performed according to the method of Box and Cox (1964), that assumes the selection of an ideal lambda value $\left(\mathrm{Y}^{\lambda}\right)$ for all the data. For all statistics used, the significance level of $\alpha=0.05$ was considered. To assess the 
behaviour of abundance, richness, Shannon diversity and Simpson's dominance (Table 1), the parameters were calculated in periods of approximately 15 days, throughout the twelve months assessed. With the calculated values, graphs were generated for the collection periods and subdivided according to the seasons: winter, spring, summer and autumn. This graphic analysis was used to analytically verify patterns and alterations of the parameters calculated throughout the collection period, as well as the influence of the seasons. The Jaccard and Bray-Curtis dendrogram of similarity was prepared to verify the degree of association between the assessed treatments.

The statistical analyses of mean test, repeated measures and Box-Cox transformation were performed with the software SAS V. 9.1 (Sas Institute Inc., 2004). The software Past (Hammer et al., 2001) was used to calculate the parameters of abundance, species richness, Shannon diversity and Simpson's dominance, and the Jaccard and Bray-Curtis similarity dendrogram. Tabulation, edition, manipulation, and further calculations and graphs were performed with Microsoft ${ }^{\circledR}$ Excel 2013.

\section{Results}

\subsection{Analyses of Scolytinae Fauna}

During the assessed period, a total of 5111 individuals belonging to 23 species of bark beetles were collected in the three treatments analyzed in an olive culture. Hypothenemus eruditus, Xyleborus linearicolis and Hypothenemus seriatus were the species with the highest occurrence considering the three treatments assessed, with 1931, 1009 and 800 individuals collected, respectively (Table 2).

Table 2. Scolytinae fauna collect in olive cultivation

\begin{tabular}{|c|c|c|c|c|}
\hline \multirow{2}{*}{ Species } & \multicolumn{3}{|c|}{ Treatments } & \multirow{2}{*}{ Total } \\
\hline & T1 & T2 & $\mathrm{T} 3$ & \\
\hline Cnesinus dryografus (Schedl, 1951) & 12 & 17 & 17 & 46 \\
\hline Criptocarenus diadematus (Eggers, 1937) & 15 & 5 & 11 & 31 \\
\hline Criptocarenus hevea (Hagedorni, 1912) & 38 & 24 & 33 & 95 \\
\hline Criptocarenus seriatus (Eggers, 1933) & 119 & 109 & 66 & 294 \\
\hline Hypothenemus eruditus (Westwood, 1836) & 579 & 920 & 432 & 1931 \\
\hline Hypothenemus seriatus (Eichhoff, 1972) & 243 & 382 & 175 & 800 \\
\hline Hypothenemus bolivianus (Eggers, 1931) & 67 & 51 & 22 & 140 \\
\hline Xyleborus affinis (Eichhoff, 1868) & 46 & 68 & 69 & 183 \\
\hline Xyleborus ferrugineus (Fabricius, 1801) & 49 & 60 & 55 & 164 \\
\hline Xyleborus hagedorni (Iglesias, 1914) & 19 & 13 & 5 & 37 \\
\hline Xyleborus linearicolis (Schedl, 1937) & 486 & 299 & 224 & 1009 \\
\hline Xyleborus sentosus (Eichhoff, 1868) & 0 & 0 & 1 & 1 \\
\hline Xyleborus biseriatus (Schedl, 1963) & 43 & 34 & 12 & 89 \\
\hline Xyleborus brasiliensis (Eggers, 1928) & 15 & 8 & 5 & 28 \\
\hline Microcorthylus minimus (Schedl, 1950) & 13 & 5 & 9 & 27 \\
\hline Corthylus nudipennis (Schedl, 1950) & 5 & 5 & 5 & 15 \\
\hline Corthylus pharax (Schedl, 1976) & 3 & 3 & 0 & 6 \\
\hline Corthylus puntactus (Eggers, 1943) & 19 & 17 & 19 & 55 \\
\hline Corthylocurus vernaculus (Schedl, 1939) & 33 & 33 & 28 & 94 \\
\hline Tricolus subincisuralis (Schedl, 1939) & 31 & 15 & 15 & 61 \\
\hline Hylocurus bidentatus (Schedl, 1950) & 0 & 2 & 1 & 3 \\
\hline Tricolus sp. & 1 & 0 & 0 & 1 \\
\hline Monarthum brasiliensis (Schedel, 1939) & 1 & 0 & 0 & 1 \\
\hline Total & 1837 & 2070 & 1204 & 5111 \\
\hline
\end{tabular}

Note. T1: homogeneous olive culture; T2: heterogeneous area of olive culture; T3: border area.

In the heterogeneous area (T2), 2070 individuals were collected (17 sample-trees, with an average of $121.8^{\mathrm{B}}$ individuals per tree), followed by the homogeneous area (T1) with 1837 (15 sample-trees, with an average of $122.5^{\mathrm{B}}$ individuals per tree), and the border area (T3) with 1204 individuals (7 sample-trees, with an average of 
172. $0^{\mathrm{A}}$ individuals per tree) (Table 3). On average, the highest abundance value was found for $\mathrm{T} 3$, which differed statistically in relation to $\mathrm{T} 1$ and $\mathrm{T} 2$. The results confirmed the highest abundance and diversity of insects in border areas (T3), since they represent the remainings of native forest, eucalyptus reforestation and meadows.

Table 3. Ecological parameters measured according to treatments in the olive orchard

\begin{tabular}{llll}
\hline \multirow{2}{*}{ Variables } & \multicolumn{3}{c}{ Treatments } \\
\cline { 2 - 4 } & $\mathrm{T} 1$ & $\mathrm{~T} 2$ & $\mathrm{~T} 3$ \\
\hline Abundance (individuals/tree ${ }^{-1}$ ) & $122.5 \mathrm{~B}^{*}$ & $121.8 \mathrm{~B}^{*}$ & $172.0 \mathrm{~A}^{*}$ \\
Richness (S) & 21 & 20 & 20 \\
Shannon diversity index (H') & $2.055 \mathrm{a}^{* *}$ & $1.826 \mathrm{~b}^{* *}$ & $2.070 \mathrm{a}^{* *}$ \\
Simpson's dominance index (D) & 0.804 & 0.741 & 0.805 \\
Pielou evenness index (J') & 0.675 & 0.609 & 0.691 \\
\hline
\end{tabular}

Note. T1: homogeneous olive culture; T2: heterogeneous area of olive culture; T3: border area. ${ }^{*}$ Test of average by Tukey-Kramer, averages followed by the same letter do not differ from each other $(\mathrm{p}<0.05)$. ${ }^{* *}$ Shannon index (H') followed by the same letter did not differ by Hutcheson's t-test $(p<0.05)$.

Richness (S) remained stable, with around 20 species collected in each treatment. Shannon diversity (H'), Simpson's dominance (D) and Pielou evenness (J') were higher for border areas (T3), followed by the homogeneous area (T1) and the heterogeneous area (T2). There was a statistical difference of the Shannon diversity index (H') in the heterogeneous area (T2), indicating lower diversity in relation to T3 and T1. Based on the value calculated for the Simpson's index (D), T1 and T3 showed higher diversity, with almost identical values. All in all, the border area (T3) showed the highest diversity according to the calculated indices (H') and (D).

\subsection{Repeated Measures Analysis}

The repeated measures ANOVA for abundance $(\mathrm{N})(\mathrm{p}=0.2775)$ and richness $(\mathrm{S})(\mathrm{p}=0.4763)$ did not show significant differences between the treatment $\times$ time interaction (Treat $\times$ Time) (Table 4). The analysis of abundance $(\mathrm{N})$ and richness $(\mathrm{S})$ of bark beetles in relation to the effect of Treatment $(\mathrm{p}=0.0007 ; \mathrm{p}=0.0010)$ and Time $(\mathrm{p}<0.0001 ; \mathrm{p}<0.0001)$ indicated the occurrence of differences for these effects.

Table 4. ANOVA with repeated measures in time for the variables abundance $(\mathrm{N})$ and richness $(\mathrm{S})$ of species of bark beetles in olive cultivation

\begin{tabular}{lllllll}
\hline Variable & $*$ Box-Cox $(\mathrm{Y}+0.5)^{\lambda}$ & Interaction & GL Num & GL Den & Value F & $\mathrm{p}>\mathrm{F}$ \\
\hline \multirow{3}{*}{ Abundance $(\mathrm{N})$} & \multirow{2}{*}{$\lambda=0.2$} & Treatment & 2 & 36 & 8.99 & 0.0007 \\
& & Time & 22 & 792 & 18.50 & $<0.0001$ \\
& & Treat $\times$ Time & 44 & 792 & 1.12 & 0.2775 \\
& & Treatment & 2 & 36 & 8.36 & 0.0010 \\
Richness (S) & $\lambda=0.6$ & Time & 22 & 792 & 9.51 & $<0.0001$ \\
& & Treat $\times$ Time & 44 & 792 & 1.00 & 0.4763 \\
\hline
\end{tabular}

Note. ${ }^{*} \mathrm{Y}=$ dependent variable; $\lambda=$ value of the power found by the transformation of the dependent variable $(\mathrm{Y})$ according to the Box-Cox method (1964); GL Num = degrees of freedom of the numerator GL Den = degrees of freedom of the denominator.

According to the graphic analysis, it can be verified that ANOVA with repreated measures did not show significant difference in the treatment $\times$ time interaction (Treat $\times$ Time), confirming that abundance $(\mathrm{N})$ and richness $(\mathrm{S})$ follow the same pattern in treatments throughout time (Figure 2). In the assessement of abundance, it was verified that spring showed the highest concentration of Scolytinae individuals (Figure 2a).

In general, the graphic analysis of richness (S) throughout the collection period showed the same tendency for the three treatments assessed, with a minimum of three and maximum of fifteen species sampled by collection period (Figure 2b). This result does not reflect the total richness obtained throughout the monitoring year (Table 
3), it reflects the fluctuation resulting from the richness of species sampled according to the analyzed treatments in relation to the influence of the four seasons and the meteorological aspects per collection.
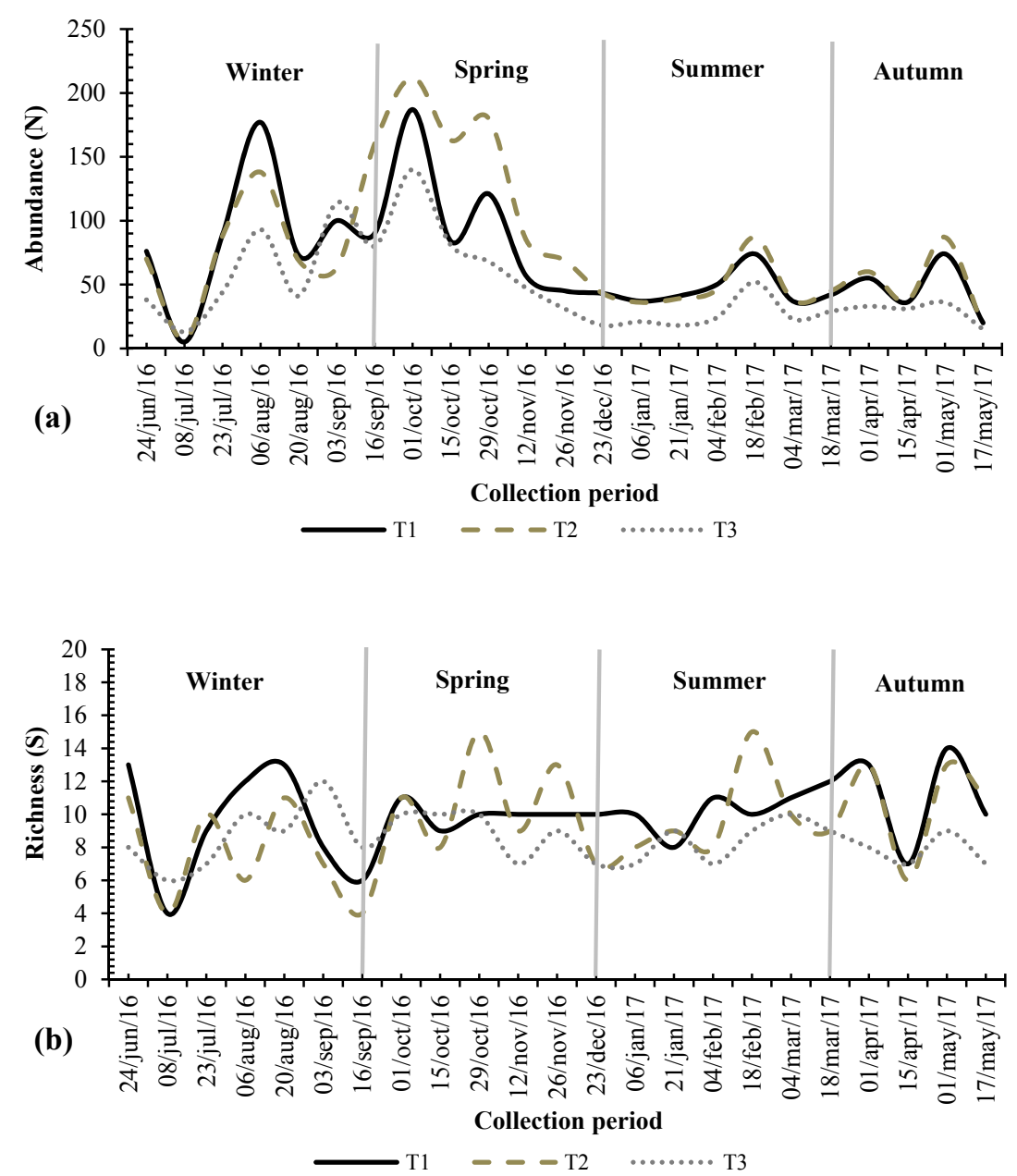

Figure 2. Graphical analysis of the variables abundance $(\mathrm{N})$ and richness $(\mathrm{S})$ in the time of the species of beetles in olive orchard

The analysis of Shannon diversity (H') and Simpson's dominance (D) indices evidenced higher diversity in the border area (T3) (Table 3). Regarding the graphic analysis, which indicates fluctuation of diversity per collection period, it was possible to verify an increase of diversity during winter, specially in August 2016 (Figure 3), due to the increase in temperature (Figure 1). The diversity underwent some oscillations in spring and summer, following an increasing tendency. 

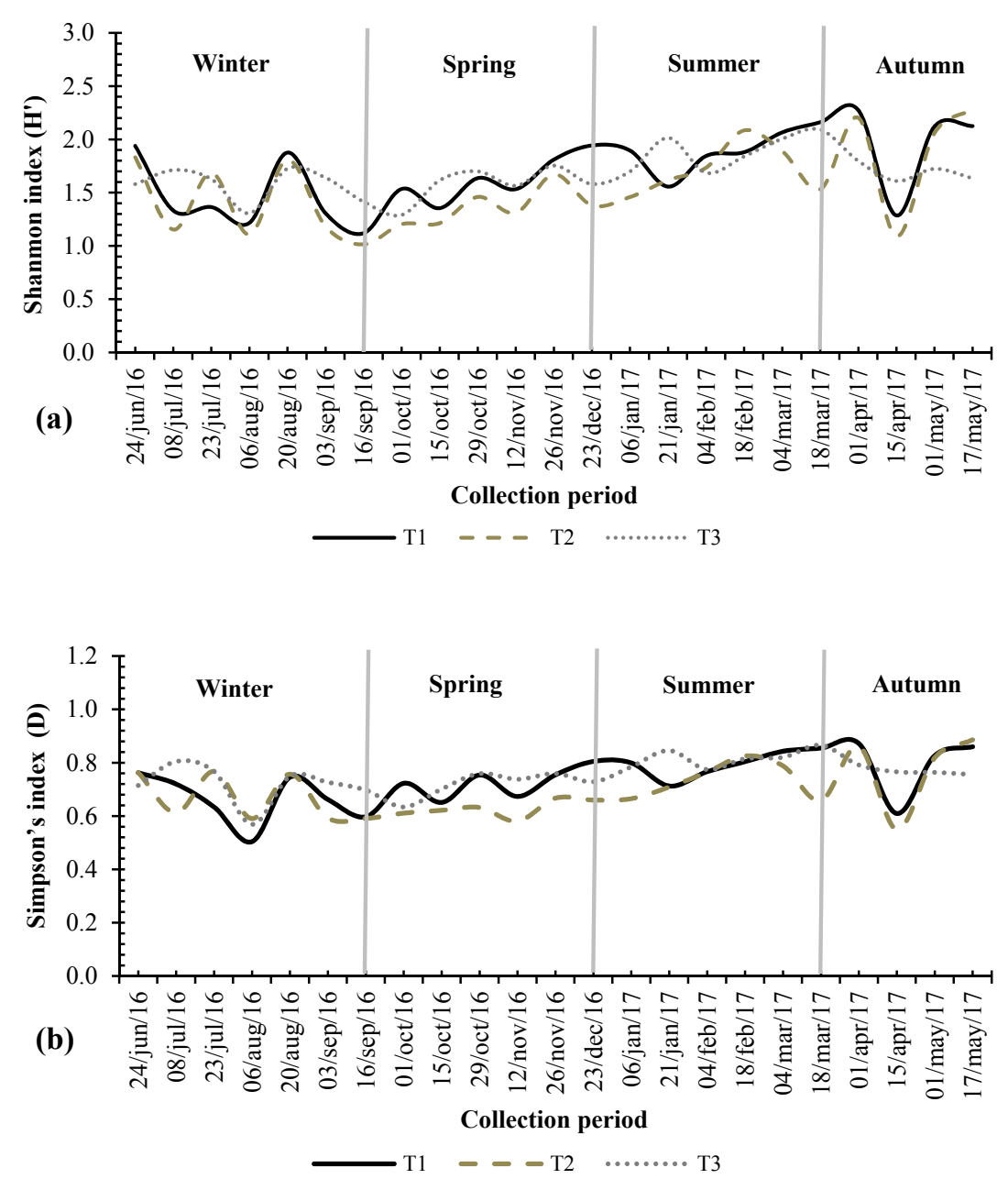

Figure 3. Graphical analysis of the Shannon diversity indexes (H') and Simpson dominance (D) of species of bark beetles in olive orchard

\subsection{Similarity Between Treatments}

The formation of two groups was observed by the Jaccard similarity index $(\mathrm{Sj})$, the first with data obtained from the heterogeneous area (T2) and the border area (T3), and the second with data obtained from the homogeneous area (T1) (Figure $4 \mathrm{a})$. The first group showed qualitatively higher similarity $(\mathrm{Sj}=0.86)$ compared to the second group $(\mathrm{Sj}=0.81)$ (Figure $4 \mathrm{a})$.

For the Bray-Curtis similarity, there was the formation of two groups, the first with the border area (T3) and the second with heterogeneous (T2) and homogeneous (T1) olive cultures (Figure 4b). The formation of these groups evidenced that the border area (T3) showed higher abundance of individuals of bark beetles, confirming the result of the mean test in Table 3. 

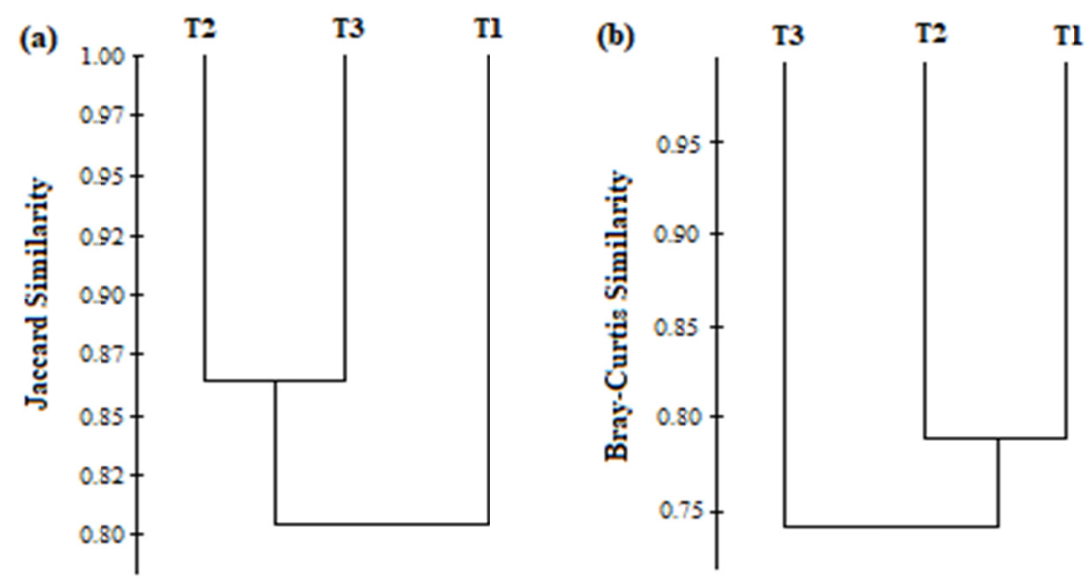

Figure 4. Dendrogram of similarity of bark beetles species: (a) Jaccard Similarity; (b) Bray-Curtis Similarity

Note. T1: homogeneous olive culture; T2: heterogeneous area of olive culture; T3: border area.

\section{Discussion}

Among the bark beetles collected, the genera Hypothenemus and Xyleborus stand out (Table 2). These are frequent in studies about characterization of Scolytinae fauna. The genus Hypothenemus shows a great variability regarding their feeding habit, which overlaps their development in relation to other genera of bark beetles (Machado \& Costa, 2017). In a study performed in a forest of Acacia mearnsii that assessed the population of bark beetles, around $55.6 \%$ of the species collected were H. eruditus (Machado et al., 2014). The predominance of this species has also been reported in forests of Pinus taeda (Costa et al., 1992), Pinus elliottii, Araucaria angustifolia, Eucalyptus dunnii (Carrano-Moreira \& Pedrosa-Macedo, 1994), Eucalyptus grandis (Flechtmann et al., 2001), and in areas of permanent preservation of the Cerrado (Dorval \& Peres-Filho, 2001).

The species of the genus Xyleborus are responsible for causing significant damage to forests, due to their xylomycetophagous feeding habits. In the present study, the species $X$. linearicolis (Table 2) was evidenced, however, it has not caused any damage to the olive trees such as the drilling of the tree stem, which is the main characteristic of the attack of bark beetles. The presence of these insects in olive orchards is probably related to the attraction bark beetles have for the smell of ethanol. Abreu et al. (2012) found that the genus Xyleborus was predominant in the primary forests of Central Amazon as well as in the Cerrado (Dorval \& Peres-Filho, 2001) and the Caatinga (Macedo-Reis et al., 2016), Eucalyptus spp. forests (Dorval et al., 2004) and Pinus sp. (Zanuncio et al., 2002).

The presence of bark beetles in treatments $\mathrm{T} 1$ and $\mathrm{T} 2$ is likely to have occurred because insects were migrating from border zones to planting areas (Table 3). In the studied area, bark beetles were observed in the sample-trees near the border area, revealing a spatial dependence, and this effect was confirmed through an analysis of spatial distribution of bark beetles (Silva, 2018).

The densification of vegetation that forms treatment T3 can be associated with the increase in population and diversity of individuals of bark beetles (Figure 3). Areas with higher density of vegetal species show an increase in the relative humidity and temperature, and these factors are favourable for the development of species of bark beetles, the hotter and more humid a site is, the better the adaptation of these insects is (Beaver, 1977). Also, there is the accumulation of plant litter in dense areas, what can interfere positively with the development of bark beetles. The highest density of individuals of bark beetles in forested areas is usually related with the highest deposition of plant litter (Meurer et al., 2013).

Spring usually shows the greatest abundance of individuals of bark beetles since the meteorological variables (temperature, precipitation, relative humidity) offer favourable conditions for the development of these insects (Figure 2a). Studies performed by Machado et al. (2014) and Bernardi et al. (2010) assessing the population fluctuation of bark beetles revealed a higher occurrence of these insects in spring and summer.

Temperature is an important meteorological variable since it stimulates the beginning of bark beetles' flight and in a general context, these insects demand a minimum temperature of $16^{\circ} \mathrm{C}$ approximately (Marques, 1984). For the genus Xyleborus, specifically, the ideal temperature for the beginning of flight is approximately $21{ }^{\circ} \mathrm{C}$ (Samaniego \& Gara, 1970). 
The reduction of the population of bark beetles from December 2016 to February 2017, corresponding to summer, is poosibly associated with the increase of values of average temperatures $\left(23.8^{\circ} \mathrm{C}\right)$ (Figures 1 and 2 ). In contrast, the population increase during winter can be considered an atypical event, because pruning was carried out in June 2016 (Figures 1 and 2), and the olive trees could have released phenolic compounds, and this could have influenced the attraction of bark beetles for the olive orchard. In addition, a positive correlation was observed with the temperature increase during July and August 2016 (Figure 1), interfering with the increase of the population of bark beetles (Figure 2a).

The Jaccard similarity index (Figure 4a) among the assessed treatments can be associated with the homogeneity of richness among bark beetles species (Table 3). For the Bray-Curtis similarity (Figure 4b), the border area (T3) has probably differed from the others due to plant density, what creates favourable conditions for the development of individuals of bark beetles.

\section{Conclusion}

The population fluctuation of bark beetles is related to the meteorological variables of temperature, precipitation and relative humidity. With the inclusion of pollinating cultivars in heterogeneous plantings, they can present a higher variation of richness fluctuation, due to the fact that they emit substances and phenolic compounds different from the ones obtained in homogeneous plantings, promoting the attraction of certain species of bark beetles, thus increasing the richness but not necessarily the abundance.

Future research related to the monitoring of Scolytinae in olive orchards in Brazil must be elaborated to ascertain whether the main pest bark beetle, Phloeotribus scarabaeoides, is occurring and attacking orchards in Brazil, since there are no records of this species as a pest of olive culture so far. Also, it is important to investigate whether other species of bark beetles are predating and consequently causing loss in olive orchards in Brazil.

\section{References}

Abreu, R. L. S., Ribeiro, G. A., Vianez, B. F., \& Sales-Campos, C. (2012). Insects of the Subfamily Scolytinae (Insecta: Coleoptera, Curculionidae) Collected with Pitfall and Ethanol Traps in Primary Forests of Central Amazonia. Psyche: A Journal of Entomology, 2012(10). https://doi.org/10.1155/2012/480520

Akuzzu, E., Guzel, H., \& Evcin, O. (2017). Effects os Stand Composition and Site Index of Pine Forests on Bark Beetle, Ips sexdentatus (Coleoptera: Curculionidae: Scolytinae) Population. Pakistan Journal Zoology, 49(4), 1449-1453. https://doi.org/10.17582/journal.pjz/2017.49.4.1449.1453

Alvares, C. A., Stape, J. L., Sentelhas, P. C., Gonçalves, J. L. M., \& Sparovek, G. (2013). Köppen's climate classification map for Brazil. Meteorologische Zeitschrift, 22(6), 711-728. https://doi.org/10.1127/ 0941-2948/2013/0507

Beaver, R. A. (1977). Bark and ambrosia beetles in tropical forests. Biotrop Special Publication, 2, 133-149.

Bernardi, O., Garcia, M. S., Silva, E. J. E., Zazycki, L. C. F., Bernardi, D., Miorelli, D., ... Finkenauer, E. (2010). Coleópteros coletados com armadilhas luminosas e etanólicas em plantio de Eucalyptus spp. no sul do Rio Grande do Sul. Ciência Florestal, 20(4), 579-588. https://doi.org/10.5902/198050982416

Box, G. E. P., \& Cox, D. R. (1964). An analysis of transformations. Journal of the Royal Statistical Society, Series B (Methodological), 26(2), 211-243.

Brower, J. E., \& Zar, J. H. (1984). Field and laboratory methods for general ecology (2nd ed.). Dubuque: Brown Publishers.

Carrano-Moreira, A. F., \& Pedrosa-Macedo, J. H. (1994). Levantamento e análise faunística da família Scolytidae (Coleoptera) em comunidades florestais no estado do Paraná. Anais da Sociedade Entomológica do Brasil, 23(1), 115-126.

Costa, E. C., Link, D., Marques, E. M., Grutzmacher, A. D., \& Silva, N. H. A. (1992). Scolytidae de Santa Maria e arredores. II-Associados a Pinus spp. E Pinus taeda (pp. 928-933). $7^{\circ}$ Congresso Florestal Estadual, Nova Prata.

Coutinho, E. F., Jorge, R. O., Haerter, J. A., \& Costa, V. B. (2015). Oliveira: Aspectos técnicos e cultivos no Sul do Brasil (1st ed.). Brasília.

Dorval, A., \& Peres-Filho, O. (2001). Levantamento e flutuação populacional de coleópteros em vegetação do Cerrado da Baixada Cuiabana, MT. Ciência Florestal, 11(2), 171-182. https://doi.org/10.5902/19805 0981665 
Dorval, A., Peres-Filho, O., \& Marques, E. M. (2004). Levantamento de Scolytidae (Coleptera) em plantações de Eucalyptus spp. Em Cuiabá, estado de Mato Grosso. Ciência Florestal, 14(1), 47-58. https://doi.org/ 10.5902/198050981780

Egonyu, J. P., Mukasa, Y., Ekwaru, R., Ogari, I., \& Ahumuza, G. (2017). Occurrence of Euwallacea sp. (Coleoptera: Scolytidae) and its ambrosia fungus Cunninghamella echinulata on Ricinus communis in Coffea canéfora gardens in Uganda. International Journal of Tropical Insect Science, 37(3), 198-207. https://doi.org/10.1017/S1742758417000121

Flechtmann, C. A. H., Couto, H. T. Z., Gaspareto, C. L., \& Berti Filho, E. (1995). Scolytidae em reflorestamentos com pinheiros tropicais. IPEF, Piracicaba.

Flechtmann, C. A. H., Ottati, A. L. T., \& Berisford, C. W. (2001). Ambrosia and bark beetles (Scolytidae: Coleoptera) in pine and eucalypt stands in southern Brazil. Forest Ecology and Management, 142(1), 183-191. https://doi.org/10.1016/S0378-1127(00)00349-2

Gallo, D., Nakano, O., Carvalho, R. P. L., Baptista, G. C., Berti Filho, E., Parra, J. R. P., ... Omotto, C. (2002). Entomologia Agrícola. Piracicaba: FEALQ.

González, R., \& Campos, M. (1994). A preliminary study of the effect of attacks by Phloeotribus scarabaeoides on the productivity of the olive trees (Olea europaea L). Bulletín de la Société entomologique de France, 67.

Hammer, O., Harper, D. A. T., \& Ryan, P. D. (2001). PAST: Paleontological Statistics Software Packge for Education and Data Analysis. Palaeontologia Electronica, 4(1), 1-9.

Hanula, J. L., Mayfield, A. E., Fraedrich, S. W., \& Rabaglia, R. J. (2008). Biology and Host Associations of Redbay Ambrosia Beetle (Coleoptera: Curculionidae: Scolytinae), Exotic Vector of Laurel Wilt Killing Regbay Trees in the Southeastern United States. Jounal of Econimic Entomology, 101(4), 1276-1286. https://doi.org/10.1093/jee/101.4.1276

Hutcheson, K. (1970). A test for comparing diversities based on the Shannon formula. Journal of Theoretical Biology, 29(1), 151-154. https://doi.org/10.1016/0022-5193(70)90124-4

IBGE (Instituto Brasileiro de Geografia e Estatística). (2004). Mapa de biomas do Brasil. Primeira aproximação Brasília: IBGE e Ministério do Meio Ambiente.

Macedo-Reis, L. E., Novais, S. M. A., Monteiro, G. F., Flechtmann, C. A. H., Faria, M. L., \& Neves, F. S. (2016). Spatio-Temporal Distribution of Bark and Ambrosia Beetles in a Brazilian Tropical Dry Forest. Journal os Insect Science, 16(48), 01-09. https://doi.org/10.1093/jisesa/iew027

Machado, L. M., \& Costa, E. C. (2017). Altura de voo de escolitíneos (Coleoptera, Scolytinae) em povoamento de Pinus taeda L. no Sul do Brasil. Ciência Florestal, 27(2), 669-678. https://oi.org/10.5902/ 1980509827751

Machado, L. M., Costa, E. C., Magistrali, I. C., Machado, D. N., \& Garlet, J. (2014). Escolitíneos associados a uma população de Acácia-negra (Acacia mearnsii De Wild). Biotemas, 27(1), 57-63. https://doi.org/ $10.5007 / 2175-7925.2014 \mathrm{v} 27 \mathrm{n} 3 \mathrm{p} 57$

Magurran, A. E. (2013). Medindo a diversidade biológica. Editora UFPR, Curitiba.

Marques, E. N. (1984). Scolytidae e Platypodidae em Pinus taeda (Dissertação, Universidade Federal do Paraná, Curitiba).

Meurer, E., Battirola, L. D., Colpani, D., Dorval, A., \& Marques, M. I. (2013). Scolytinae (Coleoptera, Curculionidae) associados a diferentes fitofisionomias no Pantanal de Cáceres, Mato Grosso. Acta Biológia Paranaense, 42(3), 195-210. https://doi.org/10.5380/abpr.v42i1-4.35214

Moeck, H. A. (1981). Ethanol induces attack on trees of spruce beetles, Dendroctonus rufipennis (Coleoptera: Scolitydae). Canadian Entomologist, 113, 939-942. https://doi.org/10.4039/Ent113939-10

Murari, A. B., Costa, E. C., Boscardin, J., \& Garlet, J. (2012). Modelo de armadilha etanólica de interceptação de voo para captura de escolitíneos (Curculionidae: Scolytinae). Pesquisa Florestal Brasileira, 32, $115-117$. https://doi.org/10.4336/2012.pfb.32.69.115

Rodríguez, E., Campos, M., Sánchez-Raya, A. J., \& Penã, A. (2003). Effect of the combined treatment of insecticides and na attractant for the control of Phloeotribus scarabaeoides, a pest of Olea europaea. Pest Management Science, 59, 339-346. https://doi.org/10.1002/ps.643 
Ruano, F., Campos, M., Sánchez-Raya, A. J., \& Peña, A. (2010). Olive trees protected from the olive bark beetle, Phloeotribus scarabaeoides (Bernard 1788) (Coleoptera, Curculionidae, Scolytinae) with a pyrethroid insecticide: Effect on the insect community of the olive grove. Chemosphere, 80, 35-40. https://doi.org/ 10.1016/j.chemosphere.2010.03.039

Samaniego, A., \& Gara, R. I. (1970). Estudios sobre la actividad de vuelo y selección de huéspedes por Xyleborus spp. y Platypus spp. (Coleoptera: Scolytidae y Platypodidae). Turrialba, 20, 471-477.

SAS Institute. (2004). SAS/STAT. User's guide: Release 9.1 (3rd ed.). Cary: SAS Institute.

Silva, B. S. O., Herzog, T. T., da Silva, M. B., Gontijo, I., \& Partelli, F. L. (2017). Distribuição Espacial do Ataque da Broca-do-café no Café Conilon. Coffee Science, 12(4), 526-533. https://doi.org/10.25186/ cs.v12i4.1360

Silva, J. M. (2018). Diversidade da Entomofauna Associada à Olea europaea (Linnaeus, 1953) em Formigueiro, Rio Grande do Sul (Dissertação, Universidade Federal de Santa Maria, Santa Maria, Rio Grande do Sul).

Souza, A. L., Soares, C. P. B. (2013). Florestas Nativas: Estrutura, dinâmica e manejo. MG: Ed. UFV, Viçosa.

Souza, M. D., Sousa, N. J., Peres-Filho, O., Dorval, A., Marques, E. M., \& Jorge, V. C. (2016). Ocorrência de Scolytinae com armadilhas etanólia contendo diferentes concentrações de etanol. Espacios, 37(16), 27.

Streck, E. V., Kämpf, N., Dalmolin, R. S. D., Klamt, E., Nascimento, P. C., Schneider, P., ... Pinto, L. F. S. (2008). Solos do Rio Grande do Sul (2nd ed.). Porto Alegre: Emater, RS.

Wood, S. L. (1982). The role of pheromones, kairomones and allomones in the host selection and colonization behavior of bark beetles. Annual Review of Entomology Stanford, 27, 411-446. https://doi.org/10.1146/ annurev.en.27.010182.002211

Yamamura, K. (1999). Transformation using $(\mathrm{x}+0.5)$ to stabilize the variance of populations. Researches on Population Ecology, 41(3), 229-234. https://doi.org/10.1007/s101440050026

Zanuncio, J. C., Sossai, M. F., Couto, L., \& Pinto, R. (2002). Occurrence of Euplatypus parallelus, Euplatypus sp. (Col.: Euplatypodidae) and Xyleborus affinis (Col.: Scolytidae) in Pinus sp. in Ribas do Rio Pardo, Mato Grosso do Sul, Brazil. Revista Árvore, 26(3), 387-389. https://doi.org/10.1590/S0100-67622002000300015

\section{Copyrights}

Copyright for this article is retained by the author (s), with first publication rights granted to the journal.

This is an open-access article distributed under the terms and conditions of the Creative Commons Attribution license (http://creativecommons.org/licenses/by/4.0/). 